
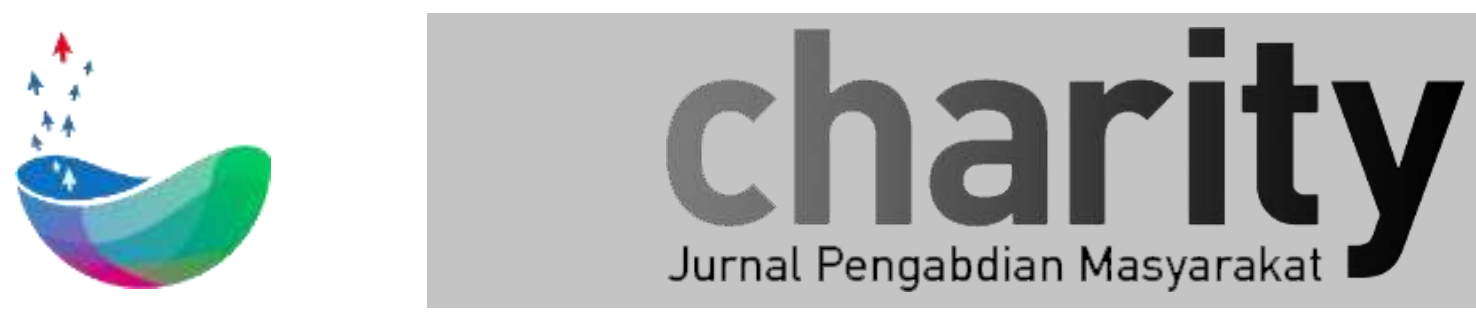

\title{
Pemanfaatan E-Commerce Dalam Peningkatan Pemasaran di UMKM Grosir Batik Tasikmalaya
}

Irfan Dharmawan ${ }^{1}$, Andreswari², Warih Puspita ${ }^{3}$

${ }^{1}$ Universitas Telkom

* dirfand@gmail.com

\section{INFO ARTIKEL}

Diterima 26 Juni 2019

Direvisi 03 Juli 2019

Disetujui 30 Agustus 2019

Tersedia Online 09 September 2019

\begin{abstract}
ABSTRAK
Pengabdian kepada masyarakat yang telah dilakukan oleh ti m PKM pengabdian adalah untuk memberikan bantuan teknis kepada Pengusaha Batik H . M a m a d dalam pengelolaan perluasan pemasaran produk batik yang berlokasi di Jl. Gn. Sabeulah, kota Tasikmalaya. Selama ini pemasaran dari batik H. Mamad masih bersifat tradisional dan tidak ada penyebaran marketing secara khusus . Dalam upaya memperluas penjualan diperlukan teknik pemasaran yang lebih baik melalui sebuah media pemasaran berbasis online. Usulan untuk menjawab tebutuhan tersebut maka akan dibuatnya system penjualan website ecommerce, yang digunakan untuk memperkenalkan dan menjual hasil produk batik, Transaksi produk, pelayanan nasabah, dan fitur lain dapat dilakukan melalui website tersebut. Dengan pemanfaatan e-commerce diharapkan dapat proses penjualan dapat meningkatkan hasil sekaligus memperluas pasar batik H. Mamad ke dunia internasional.
\end{abstract}

Keyword: Batik H. Mamad, E-

commerce, Penjualan

Korespondensi :

Direktorat Penelitian dan Pengabdian Masyarakat, Universitas Telkom

Jl. Telekomunikasi No. 1, Terusan Buah Batu, Bandung, 40257

Indonesia.

E-mail: charity@telkomuniversity.ac.id

ORCID ID: 0000-0003-0286-6476

Penulis Pertama: Irfan Dharmawan

https://doi.org/10.25124/charity.v1i01.1572

Paper_reg_number 2069 () The Authors. Published by Directorate of Research and Community Service, Telkom University.

This is an open access article under the CC BY-NC 4.0 license (https://creativecommons.org/licenses/by-nc/4.0/) 


\section{PENDAHULUAN}

Batik adalah merupakan cara pembuatan seni gambar bahan pakaian. Proses pembuatan batik bisa didasarkan pada dua hal utama, yang pertama adalah teknik melakukan pemberian warna pada kain dengan menggunakan malam untuk memberikan batasan agar warna tidak bercampur dengan sebagian dari kain. Proses ini dikenal sebagai wax-resist dyeing. Bagian kedua adalah jenis model busana dan penggunaan gambar/motif-motif tertentu yang memiliki kekhasan setiap daerah.

Batik Indonesia secara resmi dikukuhkan UNESCO menjadi warisan budaya dunia pada tahun 2009 [1,2] yang selanjutnya mulai tahun 2010 pemerintah mencanangkan hari Batik Nasional [3]. Pengakuan ini menyadarkan masyarakat untuk mengenakan produk batik sehingga berdampak positif pada perkembangan batik di Indonesia dengan ditandainya Industri Kecil Menengah (IKM) batik dan nilai ekspor yang terus tumbuh [4].

Salah satu pusat batik di Indonesia adalah Tasikmalaya. Ekspor batik Tasikmalaya ke pasar internasioal mengalami kendala pasang surut yang dikarenakan masih ada sejumlah kendala bagi pelaku usaha batik dalam sistem pemasaran yang masih tradisional.[5] Kendala ini dapat diatasi dengan memanfaatkan teknologi informasi dan telekomunikasi [6]. Teknologi informasi akan sangat membantu untuk mempopulerkan batik ke luar negeri terutama dengan adanya keterbukaan informasi.

Produk batik Tasikmalaya mempunyai ciri berupa corak batik yang lebih berani dalam warna dengan istilah corak pesisir [7]. Dari sisi motif batik kekhasan corak/motif payung, bunga, mega mendung, dengan warna yang cukup terang merupakan motif utama Tasikmalaya.

Pola manajemen yang diterapkan oleh pengusaha batik Tasikmalaya masih bersifat sederhana/ kekeluargaan. Misal dalam pencatatan bahan baku, biaya produksi, gaji karyawan, hasil penjualan dan sebagainya. Dalam pemasaran yang bersifat tradisional, dimana masih mengandalkan pengunjung mendatangi toko dan dan pesanan.

Promosi dan pemasaran khususnya keluar negeri masih menggunakan pihak ke tiga yang tentunya dapat berdampak pada keuntungan yang diperoleh. Pemasaran langsung (online) belum begitu diminati karena kekawatiran corak batik akan ditiru oleh pihak lain.

Pengusaha batik Tasikmalaya rata-rata berpendidikan SMA dan usaha batik secara turun-temurun dalam keluarga. Karyawan yang bekerja dalam setiap usaha batik antara 10-20 orang dengan pendidikan SD sampai SMA, yang bekerja dalam pembuatan batik dan pemasaran/penjualan di outlet-oulet batik di Tasikmalaya.

Mitra dalam pengabdian masyarakat ini adalah UMKM Batik H. Mamad dengan anggota karyawan sebanyak 6 orang. UMKM grosir ini berlokasi di jalan Gunng Sabeulah Ruko no. 3 Tasikmalaya.

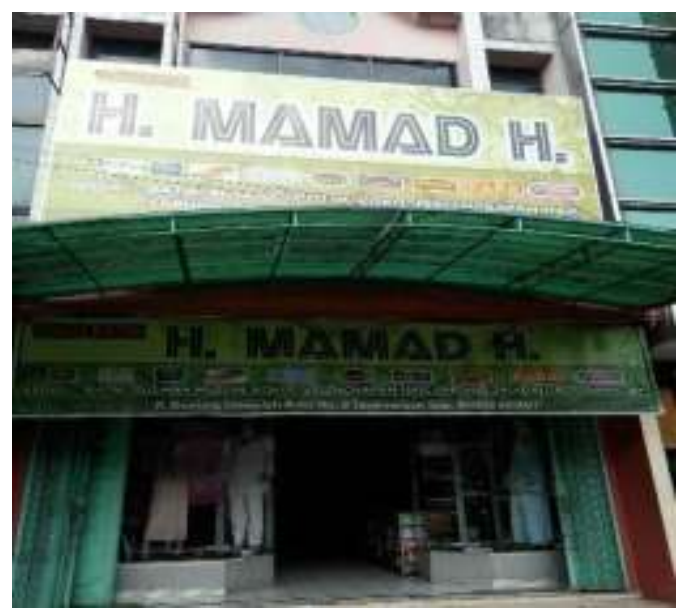


Gambar 1. Pasar Grosir H. Mamad Tasikmalaya

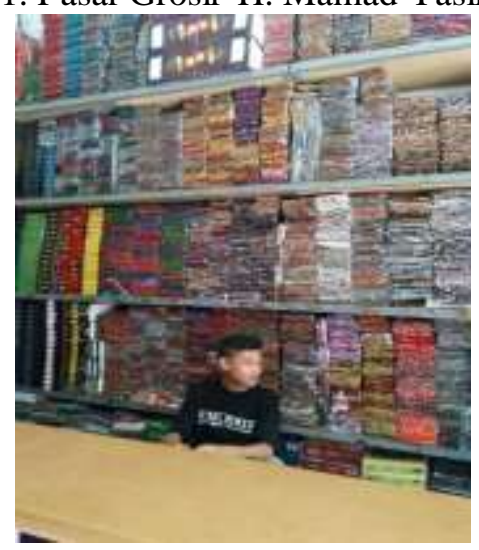

Gambar 2. Penjualan konvensional UMKM H. Mamad

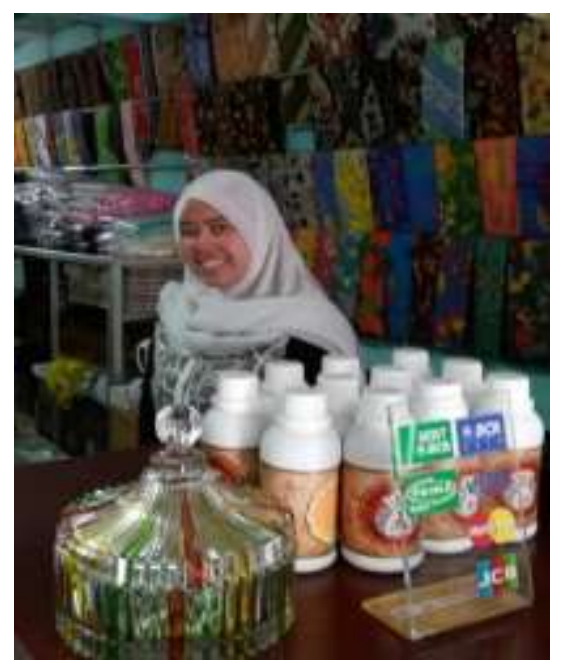

Gambar 3. Pemilik UMKM H. Mamad

\section{SOLUSI DAN TARGET LUARAN}

Pengabdian masyarakat yang dilaksanakan di Pusat Grosir H. Mamad berupa pembuatan website ecommerce [6] dan pelatihan pemanfaatan guna meningkatkan penjualan batik. Luaran kegiatan pengabdian masyarakat berupa website UMKM Pengusaha Batik H. Mamad dan keterampilan tenaga pengelola website.

\section{LANDASAN TEORI Pengertian E-Commerce}

Teknologi informasi adalah bentuk teknologi yang dimanfaatkan untuk menyalurkan, menyimpan, mengubah, dan menggunakan informasi menggunakan suatu media elektronik. Dengan adanya pemanfaatan teknologi informasi ini, perusahaan mikro, kecil maupun menengah dapat memasuki pasar yang lebih luas baik untuk pengadaan maupun penjualan barang Pemanfaatan teknologi informasi dalam menjalankan suatu bisnis atau dikenal dengan sebutan e-commerce dapat dimanfaatkan untuk perusahaan kecil sehingga dapat 
memberikan fleksibilitas dalam produksi, memungkinkan pengiriman ke pelanggan secara lebih cepat.

Pemanfaatan internet memungkinkan UMKM melakukan proses bisnisnya dengan tujuan pasar yang lebih luas, sehingga peluang menembus pasar ekspor sangat mungkin.

Electronic commerce (e-commerce) salah satu konsep yang bisa digunakan sebagai proses jual beli barang menggunakan koneksi internet atau pertukaran produk baik mentah atau jadi, jasa, dan informasi melalui jaringan informasi termasuk internet.

Menurut Kalakota dan Whinston (1997) mendefinisikan perspektif e-commerce dari beberapa aspek:

1. Perspektif komunikasi: e-commerce merupakan pengiriman informasi, produk/layanan, atau pembayaran melalui, jaringan komputer atau sarana elektronik lainnya.

2 Perspektif Proses Bisnis: e-commerce merupakan aplikasi teknologi menuju otomatisasi transaksi dan aliran kerja perusahaan sesuai proses bisnis.

3. Perspektif layanan: e-commerce merupakan salah satu alat yang memenuhi keinginan perusahaan, konsumen dan manajemen dalam memangkas biaya layanan untuk meningkatkan mutu barang dan kecepatan pelayanan.

4. Persperktif Online: e-commerce berkaitan dengan proses jual beli produk di internet dan jasa online lainnya.

\section{Perbandingan Perdagangan Konvensional Dengan Perdagangan Elektronik (E-Commerce)}

Menurut Sholekan $(2009 ; 14)$ perdagangan konvensional pada dasarnya adalah kegiatan dalam menjual barang dan/atau jasa untuk mendapatkan pendapatan dalam bentuk uang, yang pada saatnya menghasilkan laba bersih dari selisih pendapatan dikurangi harga pasar dan biaya-biaya operasional.

Perdagangan elektronik melakukan hal yang mirip dengan perdagangan tradisional namun berbasis teknologi, dan memiliki keuntungan secara langsung sehingga dapat bermanfaat untuk meningkatkan pendapatan dan keuntungan perusahaan. Keuntungan dengan menggunakan e-commerce yaitu fleksibilitasnya perdagangan elektronik dapat memangkas biaya-biaya pemasaran dengan kemudahannya dan kecanggihannya dalam menyampaikan informasi-informasi tentang barang dan jasa yang langsung ditujukan ke konsumen dimanapun mereka berada. Perusahaan yang berbisnis secara elektronik juga dapat memangkas biaya operasional, sebab tidak perlu lagi untuk menyewa/membeli toko yang berukuran besar dengan karyawan yang banyak.

\section{Meningkatkan Daya Saing UMKM Melalui E- Commerce}

Kemajuan Teknologi Informasi (TI) perlu dimanfaatkan para pelaku Usaha Mikro Kecil dan Menengah (UMKM) untuk mengembangkan usahanya melalui e-Commerce, peluangnya terbuka lebar dan secara teknis mudah dijalankan.

Dengan memanfaatkan e-Commerce dalam operasional bisnisnya, UMKM akan mendapatkan akses pasar yang lebih luas dan berpeluang menggaet pelanggan baru. Di sisi lain, pelanggan akan lebih mudah mendapatkan informasi yang diperlukan secara on-line. Berbagai penghematan dan efisiensi akan dicapai seperti dalam hal biaya, pengiriman, komunikasi telepon atau fax, dokumen, transportasi cetakan, waktu dan tenaga kerja.

\section{METODE PELAKSANAAN}

Metode pelaksanaan pengabdian masyarakat di mulai dari survei lapangan sampai pada pelaksanaan pendampingan dalam penggunaan website e- commerce.

\section{A. Survei Lapangan}

Dalam tahapan ini, tim pelaksana melakukan peninjauan secara langsung ke lokasi, melakukan wawancara dengan pengelola UMKM batik H. Mamad, dan mendapatkan data-data yang diperlukan guna membangun website e-commerce. 


\section{B. Analisis Kebutuhan}

Dari hasil survei lapangan dan wawancara terhadap pengelola UMKM Batik H. Mamad, selanjutnya dibuat rancangan awal website e- commerce yang meliputi fitur-fitur, pendalaman tentang proses bisnis [8,9] serta penetapan target pemasaran (domestik dan manca negara). Selain rancangan website ecommerce, juga merancang kebutuhan perangkat untuk kebutuhan dan pengembangan aplikasi ecommerce.

\section{Desain Aplikasi dan Pembuatan E-Commerce}

Tahapan ini adalah mendesain sistem secara keseluruhan untuk aplikasi e-commerce. Desain dibuat mulai dari rancangan database, form, dan alur aplikasi yang akan digunakan. Desain yang dihasilkan dilanjutkan dengan pembuatan website e- commerce. Alamat website: www.canting.id.

Dalam perancangan aplikasi e-commerce menggunakan framework e-commerce dari wordpress.

\section{Testing dan Evaluasi}

Dalam tahapan ini dilakukan uji fungsi fitur-fitur website. Uji fungsi ini dilakukan untuk mengetahui seluruhan fitur dan memastikan semuanya berfungsi dengan baik dan memenuhi kebutuhan konsumen.

\section{E. Pelatihan dan Pendampingan Penggunaan Website E-Commerce}

Tahapan pelaksanaan ini adalah memberikan pelatihan dan pendampingan kepada anggota dan pengelola UMKM Pusat Grosir H. Mamad.

\section{PELAKSANAAN PELATIHAN}

Pelatihan dan pendampingan pemanfaatan website e- commerce dilaksanakan di kantor UMKM Pusat Grosir H. Mamad Tasikmalaya. Sejumlah anggota dan pengelola UMKM dilatih dan diberikan pendampingan bagimana menggunakan dan mengelola website. Sejumlah fitur-fitur diperkenalkan dan langsung dicoba untuk memperkenalkan produk-produk batik. Selain itu peserta pelatihan juga diberikan pendampingan bagaimana memanfaatkan telepon seluler untuk dapat mengakses website e-commerce. Website tersebut dapat dimanfaatkan bagi pengusaha batik di pasar grosir H. Mamad untuk mengunggah setiap produknya sehingga pembeli dapat dengan mudah mendapatkan informasi mengenai produk batik yang dijual. Manfaat yang diperoleh dari hasil pengabdian (website dan pelatihan) bagi pengusaha batik adalah mempermudah mempromosikan kios/outlet, mempermudah pemasaran produk, dapat diakses di mana saja, memudahkan pembeli untuk menemukan alamat produsen batik di Pasar Grosir H. Mamad, dan memudahkan transaksi jual beli yang langsung menggunakan website e-commerce.

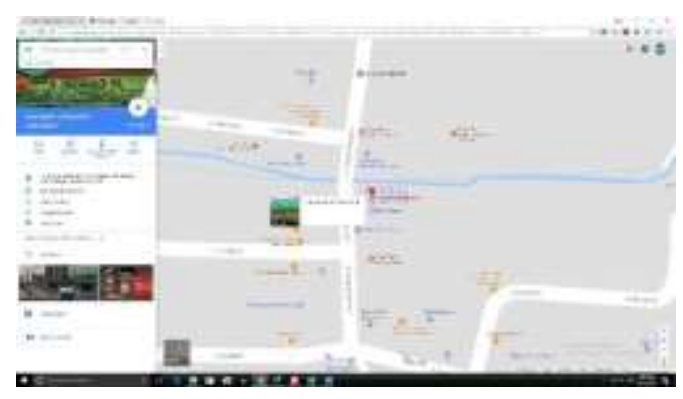

Gambar 4. Tampilan peta Kios di Pusat Grosir 


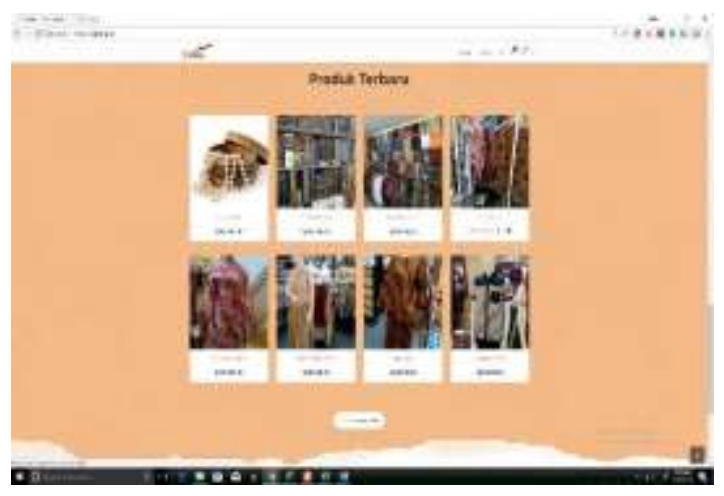

Gambar 5. Tampilan Home dari website e-commerce

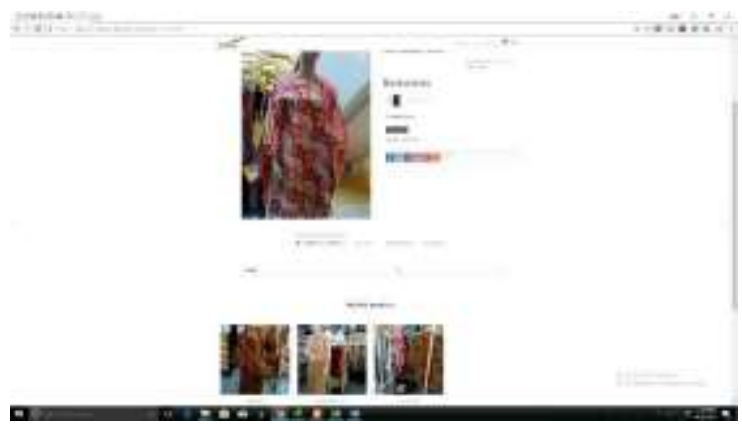

Gambar 6. Tampilan produk

\section{KESIMPULAN}

Pembuatan dan pelatihan website e-commerce di Pusat Grosir H. Mamad Tasikmalaya telah memberikan manfaat dan kemudahan para pengusaha batik untuk memasarkan produk-produknya sehingga pembeli dengan mudah dapat memperoleh informasi produk yang dijual. Website e-commerce juga memberikan kemudahan kepada pembeli dan pengusaha untuk melakukan transaski.

\section{DAFTAR PUSTAKA}

[1] Ulum, I. 2009, Batik dan Kontribusinya Terhadap Perekonomian Nasional, Jurnal Bestari 42: 21-32 http://ejournal.umm.ac.id/index.php/bestari/artic le/view/91

[2] The Global Review. 2009, http://www.theglobal- review.com/content_detail.php?lang=id\&id=728 \&type=9\#. WMfOCTi3rE8

[3] Kementerian Perindusterian Republik Indonesia.http://www.kemenperin.go.id/artikel/6 827/Dunia-Makin- Mencintai-Batik

[4] Giatno, 2015, Analisis Penerapan Strategi PemasaranDalam Upaya Meningkatkan Penjualan Batik di Batik Putra Laweyan, naskah publikasi, Universitas Muhammadiyah Surakarta, Jan. 2015. http://eprints.ums.ac.id

[5] $\begin{array}{ll}\text { T35642/9/010.\%20Naskah\%20Publikasi.pdf } \\ \text { Tribun }\end{array}$ http://ww w.tribunnews.com/bisnis/2014/04/01/kur ang-pemasaran-kesalahan-utama-batikTasikmalaya

[6] T. Hariyati. 2014. Analisis dan Perancangan E_CommercePada Batik Tulis Tengah Sawah Ngadirojo, IJNS-Indonesian Journal on Networking and Security 3(2): 21-25. http://ijns.org/journal/index.php/ijns/ article/view/33

[7] M. Yulianti, 2006, Kajian Strategi dan Bauran Pemasaran Batik Garutan, laporan akhir, Sekolah Pascasarjana Institut Pertanian Bogor,. https://core.ac.uk/download/pdf/ 32345157.pdf 